\title{
Argyle Shared Street Methods
}

Research Fellow:

Sarah Hanson

Adjunct Professor

Illinois Institute of Technology

Research Assistant:

Matthew Callone

MLA Candidate

Illinois Institute of Technology

Firm Liaison:

Brenda Kiesgen

Project Manager

site design group

Firm Liaison:

Ellen Schmidt

Project Manager

site design group

This investigation was conducted as part of the Landscape Architecture Foundation's 2019 Case Study Investigation (CSI) program. CSI matches faculty-student research teams with design practitioners to document the benefits of exemplary high-performing landscape projects. Teams develop methods to quantify environmental, social, and economic benefits and produce Case Study Briefs for LAF's Landscape Performance Series.

To cite:

Hanson, Sarah, and Matthew Callone. "Argyle Shared Street Methods." Landscape Performance Series. Landscape Architecture Foundation, 2019.

https://doi.org/10.31353/cs1491

The full case study can be found at: https://landscapeperformance.org/case-studybriefs/argyle-shared-street 


\section{Overview}

Located on the Argyle Street corridor known as "Asia on Argyle" and "Little Vietnam", Argyle Shared Street reclaims a traditional streetscape to provide a pedestrian-friendly area easily adaptable for community events. This is achieved by through a paved plaza landscape with sidewalks and the street placed at the same level, and planter beds that businesses often add their own plants to. Beyond providing an area reminiscent of Vietnam streetscapes conducive to lively activity across the community space, the street unit paver design offers a dual environmental purpose. The sidewalks are composed of permeable pavers that drain stormwater beneath the subgrade, while the street space drains to the planter beds that serve as infiltration beds. The following document illustrates how a street design provides environmental, social, and economic benefits that enhance the streetscape's use as a space for community gathering.

\section{Environmental Benefits}

- Provides more than double the stormwater storage volume than required by the City with a storage capacity of 7,800 gallons.

Prior to reconstruction of this segment of Argyle Street in Chicago, Illinois, the street was paved with a conventional asphalt treatment over crushed stone. Soil borings of the street section revealed a subgrade soil with a high infiltration rate (4in/hr), allowing for permeable pavement construction and infiltration planters for the new shared street. These Best Management Practices (BMPs) exceeded the stormwater capacity requirements of 3,379 gallons.

Methods: The stormwater management strategy for the Argyle Shared Street reconstruction project is a standalone system designed for detention and infiltration. As such, this system is not integrated into the combined sewer system (CSS) and is designed to detain $100 \%$ of upstream runoff. The City of Chicago Department of Water Management (DWM) performed its calculations using its "Stormwater Spreadsheet Tool 3.0" for all of the stations of the project site specified on construction drawings. A detention storage calculation determined the required detention volume of each station utilizing the Illinois State Water Survey's (ISWS) Bulletin 70 rainfall data for 5-, 10-, 25-, 50-, and 100-year storm events; each station's drainage area; and inflow, release, storage and storage volume rates (Table 1). A series of worksheets utilizing drainage area, design soil infiltration rates, and BMP dimensions provided a summary of volume control BMP storage for each station. The total required detention volume and BMP volume control was summated to show that 3,379 gallons of storage was required in order to accommodate storms on record that released at a rate less than or equal to $1.002 \mathrm{cfs}$, equating to a 10-minute $5.40 \mathrm{in} / \mathrm{hr}, 15-\mathrm{minute} 4.12 \mathrm{in} / \mathrm{hr}$ and 30-minute 2.82in/hr storm. The BMPs provided more than double the reuiqred storage (according to Table 2). The "Stormwater Spreadsheet Tool 3.0" concludes that the BMP volume control storage exceeds that required for 
the entire site; in other words, $100 \%$ of runoff within the allowable release rate is expected to be detained on site through infiltration.

Field testing was conducted for this site but failed to confirm the above calculations. A research team from EarthWatch began a three-month research study of infiltration and soil moisture of the bioswale infiltration planters at Argyle Shared Street with citizen scientist volunteers on May 10, 2019. Soil moisture and infiltration rates were taken on-site using sensors and infiltrometers at 10 different planter sites. First the surface areas of each of the 10 infiltration planter sites were measured. Infiltration rates were measured by placing single-ring infiltrometers firmly above the soil, below the mulch layer, and filling them with water to the $10 \mathrm{~cm}$ line and timing the rate at which the water infiltrated the soil. At each test location, moisture sensors were placed at $3 \mathrm{~cm}, 10 \mathrm{~cm}$ and $20 \mathrm{~cm}$ and a temperature sensor placed at $3 \mathrm{~cm}$ depth. Voltage sensor readings were taken every six hours. Unfortunately, these tests failed to yield valid results. See limitations.

Calculations:

$\frac{\text { Detention Storage Calculations }}{\text { (Based on Bulletin } 70 \text { Rainfall Data) }}$

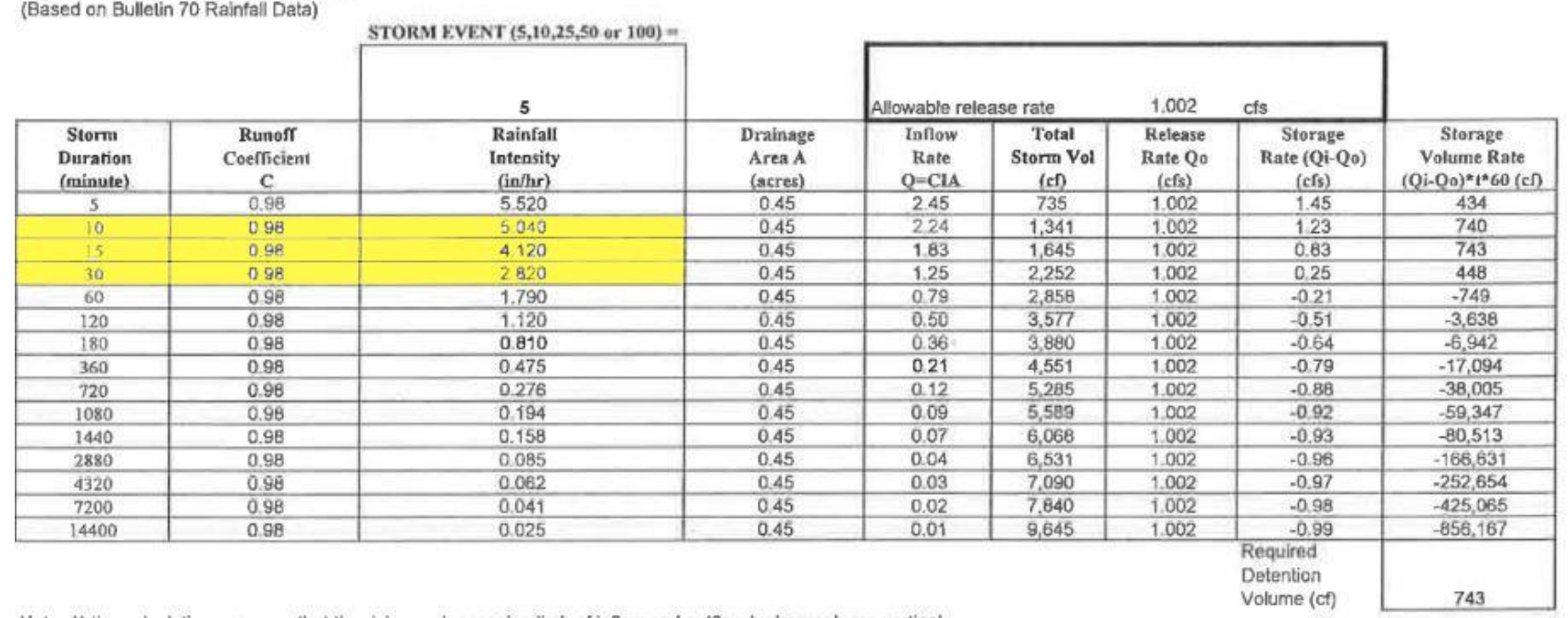

Note: 1) the calculation assumes that the rising and recessing limb of inflow and outflow hydrograph are vertical

Table 1: Detention Storage Calculations performed by Stormwater Spreadsheet Tool 3.0.

Source: City of Chicago

\begin{tabular}{|l|l|l|}
\hline Station Range & Storage Required (gallons) & Storage Provided by BMP (gallons) \\
\hline $\begin{array}{l}\text { Kenmore to Sheridan, STA } \\
20+00 \text { to STA } 23+00\end{array}$ & 795 & 2,184 \\
\hline $\begin{array}{l}\text { Winthrop to Kenmore, STA } \\
15+50 \text { to STA 20+00 }\end{array}$ & 1,197 & 3,176 \\
\hline $\begin{array}{l}\text { CTA to Winthrop, STA } 14+20 \\
\text { to STA } 15+50\end{array}$ & 346 & 913 \\
\hline At CTA, STA $12+50$ to $14+20$ & 448 & 166 \\
\hline
\end{tabular}




\begin{tabular}{|l|l|l|}
\hline Broadway to CTA & 593 & 1,396 \\
\hline TOTAL & $\mathbf{3 , 3 7 9}$ & $\mathbf{7 , 7 9 9}$ \\
\hline
\end{tabular}

Table 2: Storage required for the site and provided by the project BMPs.

Source: Burns and McDonnell Engineering

\begin{tabular}{|l|l|}
\hline Station Range & Site Area (square feet) \\
\hline Kenmore to Sheridan, STA 20+00 to STA 23+00 & 19,800 \\
\hline Winthrop to Kenmore, STA 15+50 to STA 20+00 & 29,700 \\
\hline CTA to Winthrop, STA 14+20 to STA 15+50 & 8,580 \\
\hline At CTA, STA 12+50 to 14+20 & 11,220 \\
\hline Broadway to CTA & 14,520 \\
\hline TOTAL & 72,679 \\
\hline
\end{tabular}

Table 3: Total surface area of Argyle Shared Street. Source: Burns and McDonnell Engineering.

Sources:

American Rivers, Center for Neighborhood Technology. 2011. The Value of Green Infrastructure: A Guide to Recognizing Its Economic, Social and Environmental Benefits. http://www.cnt.org/repository/gi-values-guide.pdf

Burns and McDonnell Engineering. Argyle Shared Street Stormwater Calculations. May 5, 2014. Raw data. Chicago.

*Utilizes City of Chicago Water Department Stormwater Spreadsheet Tool 3.0

GEOTECHNICAL REPORT: CDOT Streetscape Improvements Argyle Street, from Broadway Avenue to Sheridan Road CDOT Project Number S-1-323. Technical paper no. 13023. Burns and McDonnell Engineering. Naperville, IL: Geo Services, 2013.

Metropolitan Water Resources District of the Greater Chicago Region. "Committee on Budget and Employment Transmittal Letter." January 2005. http://www.mwrdgc.dst.il.us/ga/budget/2005 Final/Section I - Foreward.pdf

"Reduced Treatment Benefits." Green Values National Stormwater Management Calculator. https://greenvalues.cnt.org/national/benefits_detail.php\#reduced-treatment.

Table 1. Sectional Mean Frequency Distributions for Storm Periods of 5 Minutes to 10 Days and Recurrence Intervals of 2 Months to 100 Years in Illinois. PDF. Champaign: Illinois State Water Survey, 2007. https://www.isws.illinois.edu/statecli/RF/table10.pdf 
US Department of Commerce, and Noaa. "Annual Precipitation Rankings for Chicago, Illinois." Annual Precipitation Rankings for Chicago, Illinois. January 04, 2019. Accessed June 17, 2019. https://www.weather.gov/lot/Annual_Precip_Rankings_Chicago.

Limitations: BMPs at stations $12+50$ to $14+20$ did not provide required runoff storage for this drainage area, potentially demonstrating less than $100 \%$ runoff capture in this location despite the other stations having extra runoff storage. Furthermore, the DWM Stormwater Spreadsheet Tool 3.0 utilized storm data that were within an allowable release rate of $1.002 \mathrm{cfs}$; in other words, these stormwater requirements are not requirements for Chicago's more serious storm events on record.

Soil infiltration rates were calculated by Earthwatch after a heavy rain cycle. The soil was waterlogged and infiltration took too long for measurable data to be recorded; in almost all of the bioswales, less than a centimeter of water infiltrated in 10 minutes. In addition, EarthWatch has observed in bioswale tests at other sites that oil runoff and crusting of the surface layer contributed to the lack of water infiltration. However, the Stormwater Spreadsheet Tool 3.0 utilized the design soil infiltration rate of 3.6 in $(9.1 \mathrm{~cm})$ per hour, which equates to $1.5 \mathrm{~cm} / 10$ minutes. This is comparable to the Earthwatch test results for infiltration and as such the rate used by the Department of Water Management is a conservative estimate.

Moisture sensors installed by Earthwatch were not working well and did not yield valid data.

- Virtually eliminates the need for irrigation of the infiltration planters, saving an estimated 9,300 gallons of potable water during a typical peak watering month.

The diversion of water from the impermeable portion of the street to infiltration planters irrigates the planters with non-potable water. Supplemental irrigation with potable water is performed by landscape contractors by request only.

Methods: The bioretention and infiltration calculations conducted using the Center for Neighborhood Technology's Value of Green Infrastructure Guide were applied using the average rainfall for the month of July in Chicago to determine that approximately 113,700 gallons of stormwater would be collected by the infiltration planters during this peak watering month. The SITES Baseline Landscape Water Requirement (BLWR) calculator was used to determine that approximately 9,300 gallons would be needed to irrigate the infiltration planters in the peak watering month of July.

Calculations:

\begin{tabular}{|l|l|l|}
\hline Station Range & Infiltration Planter Area (sf) & Drainage Area (sf) \\
\hline $\begin{array}{l}\text { Kenmore to Sheridan, STA } \\
20+00 \text { to STA 23+00 }\end{array}$ & 725 & 9575 \\
\hline $\begin{array}{l}\text { Winthrop to Kenmore, STA } \\
15+50 \text { to STA 20+00 }\end{array}$ & 970 & 16995 \\
\hline
\end{tabular}




\begin{tabular}{|l|l|l|}
\hline $\begin{array}{l}\text { CTA to Winthrop, STA 14+20 to } \\
\text { STA } 15+50\end{array}$ & 275 & 4825 \\
\hline At CTA, STA $12+50$ to $14+20$ & 0 & 10745 \\
\hline Broadway to CTA & 290 & 7150 \\
\hline TOTAL & 2260 & 49290 \\
\hline
\end{tabular}

Table 4: Total area of the infiltration planters and their drainage area.

Source: Burns and McDonnell Engineering

Total Runoff Collected in July Calculation:

3.7 inches avg July precipitation * 49,290 sf site area [impervious area] * $100 \%$ rainfall captured/retained * $144 \mathrm{sq}$ inches $/ \mathrm{SF}{ }^{*} 0.00433 \mathrm{gal} /$ cubic inch $=113,700$ gallons

Amount of water required by plants:

$\mathrm{BLWR}$ (Gallons) $=\mathrm{ET}_{0} \times \mathrm{A} \times \mathrm{C}_{\mathrm{u}}=6.59 \mathrm{in} /$ month $\times 2260 \mathrm{sq} \mathrm{ft} \times 0.6233=9,300$ gallons

Where:

$\mathrm{ET}_{0}=$ Average Reference Evapotranspiration for the Site's Peak Watering Month (July)

Provided Locally in Inches/Month

$A=$ Total Area of Infiltration Planters

$\mathrm{C}_{\mathrm{u}}=$ Conversion Factor $=0.6233$ (for gallons)

\section{Sources:}

Burns and McDonnell Engineering. Argyle Shared Street Stormwater Calculations. May 5, 2014. Raw data. Chicago.

*Utilizes City of Chicago Water Department Stormwater Spreadsheet Tool 3.0

American Rivers, Center for Neighborhood Technology. 2011. The Value of Green

Infrastructure: A Guide to Recognizing Its Economic, Social and Environmental Benefits. http://www.cnt.org/repository/gi-values-guide.pdf

Limitations: The landscape maintenance crew was asked to water a few times during the summer months. The CSI research team was not able to obtain data on how often or how much water, but this would suggest that the planters could not meet $100 \%$ of irrigation needs. Incorporating daily moisture requirements of plants would provide a more accurate number of actual irrigation requirements.

The amount of water and number of days required for supplemental irrigation of planters is also speculative as it is dependent on actual annual rainfall. 


\section{Social Benefits}

- Provides improved aesthetic, environmental, cultural, and/or accessible quality as compared to a typical Chicago street design according to $96 \%$ of 48 surveyed visitors.

- Supports and enhances community events, as demonstrated by $72 \%$ of 103 surveyed Argyle Night Market participants in 2017 and 2018 reporting that the streetscape enhances their experience of the market.

A majority of respondents surveyed on Argyle Shared Street over the course of the past three years since the project's inception responded positively to questions relating to their experience on the street. A majority of respondents in a 2018 Chicago Department of Transportation survey agreed that the Argyle Shared Street provides a host of economic, social, cultural, environmental, and health-related benefits (Figure 3). A total of 2017 and 2018 Night Market surveys showed that $72 \%$ of users believed the street improvements enhanced their experience at the Night Market. Features that users most enjoyed include "the brick pavers," "pedestrian friendly layouts," and a street that "provides for programming opportunities that celebrate culture and diversity."

The Night Market is a weekly event on Thursdays in the second half of the summer. The market features regional farmers, local food, and performances.

\section{Methods:}

The LAF research team distributed surveys to 48 site users of Argyle Shared Street during the July 11th, 2019 Night Market, which asked participants if they found the street to have improved in the aesthetic, cultural, environmental or accessibility quality of the shared street compared to a typical Chicago street. $46 / 48$, or $96 \%$, or respondents selected at least one category as a quality improvement (Table 5). In the same survey, when asked what attracts them to the street, $38 / 48$, or $89 \%$ reported that restaurants do and $34 / 48$, or $79 \%$, reported that cultural aspects do (Table 6). The full survey is found in Appendix A.

The Chicago Department of Transportation (CDOT) shared the results of three surveys taken by users of the Argyle Shared Street, two of which were taken at the 2017 and 2018 Argyle Night Markets and one of which was taken from visitors during a high-traffic time on November 29th, 2018. The CDOT Night Market Surveys were taken by 72 and 31 users in 2017 and 2018, respectively. The results to those who answered "Yes" to the question "Do Shared Street improvements enhance your experience as a Night Market Visitor?" in 2017 and 2018 were calculated as a proportion of the total amount of people surveyed in 2017 and 2018 to determine the percentage for both years. Responses from the 2018 Night Market survey question "What do you like best about the Argyle Shared Street" are shared below for their relevance to perception. Questions from the November 29th, 2018 survey were selected for their relevance as a question related to perception. 
Additional survey responses relating to perceptions of benefits is below in Figures 1 and 2 .

Survey results are found in Appendix A.

Calculations:

5. Do you find this street to have improved the quality of any of the following categories in comparison with a typical street design in Chicago? (Please select all that apply)

\begin{tabular}{|c|c|c|}
\hline Aesthetic & 33 & $71.74 \%$ \\
\hline Environmental & 15 & $32.61 \%$ \\
\hline Cultural & 24 & $52.17 \%$ \\
\hline Accessibility & 21 & $45.65 \%$ \\
\hline No better quality & 2 & $4.35 \%$ \\
\hline & $46 / 48$ & \\
\hline
\end{tabular}

Table 5: User perception of street quality responses on July 11, 2019. Source: LAF Research Team

\section{What attracts you to this street?}

\begin{tabular}{|l|r|r|}
\hline Restaurants & 38 & $79.17 \%$ \\
\hline Retail & 9 & $18.75 \%$ \\
\hline Gardens/plant features & 10 & $20.83 \%$ \\
\hline Cultural aspects & 34 & $70.83 \%$ \\
\hline Other: "CTA", "Night Market" & 5 & $10.42 \%$ \\
\hline & $48 / 48$ & \\
\hline
\end{tabular}

Table 6: Elements that attract site users to Argyle Shared Street responses on July 11, 2019.

Source: LAF Research Team 


\section{Q18 The Argyle Shared Street was implemented to provide and support}

economic, social, cultural, environmental and health-related benefits for the community. Please mark the extent to which you agree with the following statements. The Argyle Shared Street provides...

\begin{tabular}{|c|c|c|c|c|c|c|c|}
\hline & \multicolumn{2}{|c|}{ Answered: 81} & Skipped: 5 & \multirow[b]{2}{*}{$\begin{array}{l}\text { STRONGLY } \\
\text { DISAGREE }\end{array}$} & \multirow[b]{2}{*}{$\begin{array}{l}\text { DON'T } \\
\text { KNOW }\end{array}$} & \multirow[b]{2}{*}{ TOTAL } & \multirow[b]{2}{*}{$\begin{array}{l}\text { WEIGHTED } \\
\text { AVERAGE }\end{array}$} \\
\hline & $\begin{array}{l}\text { STRONGLY } \\
\text { AGREE }\end{array}$ & AGREE & DISAGREE & & & & \\
\hline \multirow{2}{*}{$\begin{array}{l}\text { A safe and welcoming pedestrian } \\
\text { environment }\end{array}$} & $22.22 \%$ & $49.38 \%$ & $12.35 \%$ & $8.64 \%$ & $7.41 \%$ & & \\
\hline & 18 & 40 & 10 & 7 & 6 & 81 & 2.70 \\
\hline \multirow{2}{*}{$\begin{array}{l}\text { Opportunity to socialize more frequently } \\
\text { with friends and neighbors }\end{array}$} & $24.05 \%$ & $34.18 \%$ & $15.19 \%$ & $7.59 \%$ & $18.99 \%$ & & \\
\hline & 19 & 27 & 12 & 6 & 15 & 79 & 2.37 \\
\hline \multirow{2}{*}{$\begin{array}{l}\text { Opportunity to participate in more cultural } \\
\text { events }\end{array}$} & $25.32 \%$ & $48.10 \%$ & $11.39 \%$ & $3.80 \%$ & $11.39 \%$ & & \\
\hline & 20 & 38 & 9 & 3 & 9 & 79 & 2.72 \\
\hline \multirow{2}{*}{$\begin{array}{l}\text { Increased sense of pride in your } \\
\text { community }\end{array}$} & $25.32 \%$ & $49.37 \%$ & $11.39 \%$ & $10.13 \%$ & $3.80 \%$ & & \\
\hline & 20 & 39 & 9 & 8 & 3 & 79 & 2.82 \\
\hline \multirow{2}{*}{$\begin{array}{l}\text { Opportunity to shop locally for routine } \\
\text { goods and services }\end{array}$} & $15.19 \%$ & $45.57 \%$ & $20.25 \%$ & $5.06 \%$ & $13.92 \%$ & & \\
\hline & 12 & 36 & 16 & 4 & 11 & 79 & 2.43 \\
\hline \multirow{2}{*}{$\begin{array}{l}\text { Access to a diverse range of goods and } \\
\text { services }\end{array}$} & $16.46 \%$ & $51.90 \%$ & $18.99 \%$ & $6.33 \%$ & $6.33 \%$ & & \\
\hline & 13 & 41 & 15 & 5 & 5 & 79 & 2.66 \\
\hline \multirow{2}{*}{$\begin{array}{l}\text { Access to more outdoor cafes / } \\
\text { opportunities for outdoor dining }\end{array}$} & $26.58 \%$ & $46.84 \%$ & $16.46 \%$ & $5.06 \%$ & $5.06 \%$ & & \\
\hline & 21 & 37 & 13 & 4 & 4 & 79 & 2.85 \\
\hline \multirow{2}{*}{$\begin{array}{l}\text { A more pleasant walk to the CTA station } \\
\text { or other transit }\end{array}$} & $31.65 \%$ & $40.51 \%$ & $10.13 \%$ & $12.66 \%$ & $5.06 \%$ & & \\
\hline & 25 & 32 & 8 & 10 & 4 & 79 & 2.81 \\
\hline \multirow{2}{*}{ Convenient access to local businesses } & $22.78 \%$ & $55.70 \%$ & $13.92 \%$ & $2.53 \%$ & $5.06 \%$ & & \\
\hline & 18 & 44 & 11 & 2 & 4 & 79 & 2.89 \\
\hline \multirow[t]{2}{*}{ Less local flooding } & $13.92 \%$ & $22.78 \%$ & $6.33 \%$ & $1.27 \%$ & $55.70 \%$ & & \\
\hline & 11 & 18 & 5 & 1 & 44 & 79 & 1.38 \\
\hline \multirow[t]{2}{*}{ Opportunity to spend more time outside } & $22.78 \%$ & $39.24 \%$ & $18.99 \%$ & $3.80 \%$ & $15.19 \%$ & & \\
\hline & 18 & 31 & 15 & 3 & 12 & 79 & 2.51 \\
\hline
\end{tabular}

Figure 1: Responses to Question 18 from Argyle Shared Street Community Survey, 11-29-2018. Source: CDOT.

\section{Do Shared Street improvements enhance your experience as a Night Market Visitor?}

- $73.61 \%$ Yes

- $11.11 \%$ No

- $15.28 \%$ Don't know

Figure 2: 2017 Night Market Survey Results. Source: CDOT 


\section{Q4 Do Shared Street improvements enhance your experience as a Night Market visitor?}

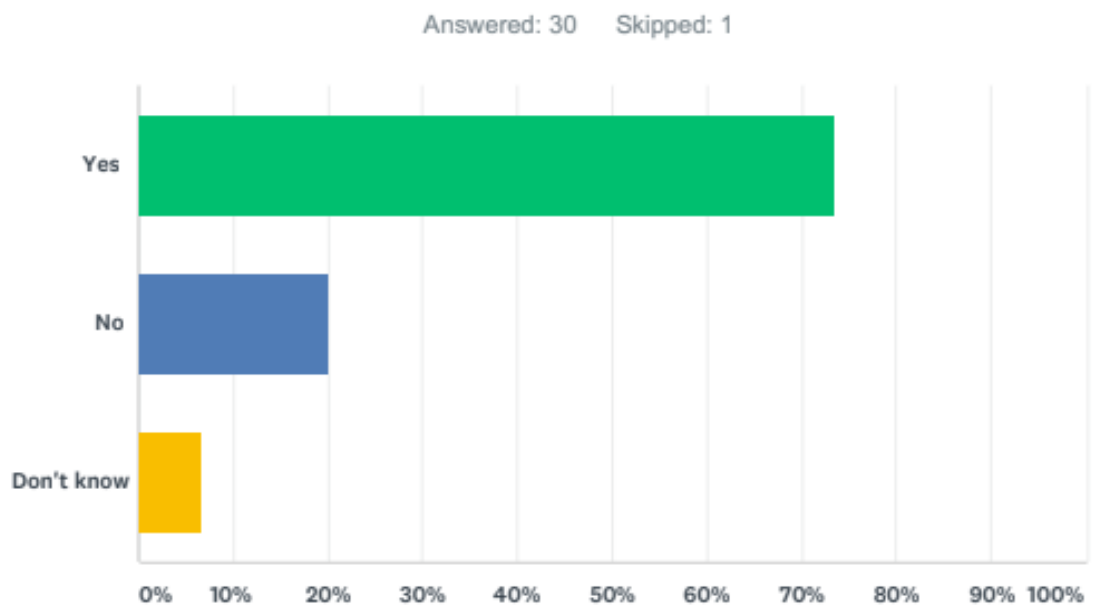

\begin{tabular}{|c|c|c|}
\hline ANSWER CHOICES & RESPONSES & \\
\hline Yes & $73.33 \%$ & 22 \\
\hline No & $20.00 \%$ & 6 \\
\hline Don't know & $6.67 \%$ & 2 \\
\hline TOTAL & & 30 \\
\hline
\end{tabular}

Figure 3: 2018 Night Market Survey Results. Source: CDOT

Do Shared Street improvements enhance your experience as a Night Market visitor?

72 total respondents $(2017)+30$ total respondents $(2018)=102$ respondents total 53 yes respondents $(2017)+22$ yes respondents $(2018)=73$ "yes" respondents total

$73 / 102=72 \%$

Sources:

Callone, Matt. Argyle Shared Street User Survey. July 2019. Raw data. Uptown, Chicago.

CDOT. 2017 Night Market Survey Data. August 31, 2017. Raw data. Argyle Shared Street, Chicago.

CDOT. 2018 Night Market Survey Data. October 22, 2018. Raw data. Argyle Shared Street, Chicago.

CDOT. Argyle Shared Street Community Survey. November 29, 2018. Raw data. Argyle Shared Street, Chicago.

Limitations: LAF Research Team surveys were taken at scheduled street events, but not at nonevent times. This may affect the results in a positive direction as people attending the events 
may have a positive bias towards the quality of the street since they are attending a street event.

The CDOT survey results from 2017 and 2018 may have included repeat respondents from both years.

- Supports increased event attendance with attendees at the Argyle Night Market growing from 25,000 in 2016 (pre-construction) to 45,000 in 2018 (postconstruction). The number of participants in the Argyle Lunar New Year Parade doubled between 2017 and 2018.

Beyond events sponsored and hosted by larger community organizations such as the Chicago Department of Transportation (CDOT) and the 48th Ward, partnerships between CDOT, the 48th Ward, and Axis Lab (a small community-based organization) have presented opportunities to host various event series in order to present the Argyle Shared Street as an opportunity for new growth and development of the corridor. The "Baseline" arts, food and music markets and "Second Fridays" events hosted in 2016 and 2017 have showcased the diversity of Chicago's Uptown community to qualify the Argyle Shared Street as an asset that supports this diversity.

Methods: Uptown United provided the participation counts for the Argyle Night Market and the Argyle Lunar New Year Parade. Argyle Night Market grew in participation from 25,000 in 2016, to 40,000 in 2017, to 45,000 in 2018. Argyle Lunar New Year Parade grew in participants from 1,000 in 2016, to 2,000 in 2017 and remained at 2,000 in 2018.

Calculations: Participants counts provided by Uptown United.

Sources:

Weidl, Justin. Argyle Street Night Market and Lunar New Year Parade 2016-2018 Attendance. Uptown United. May 9, 2019. Raw data. Chicago, Illinois.

Limitations: Event participation numbers are limited to what was collected by the source community organizations and were not independently verified by the CSI research team.

\section{Cost Comparison}

- The city could have made improvements to the streescape for approximately $\$ 529,476$ per block, which is $\$ 395,759$ less than the Argyle Shared Street per block cost of $\$ 925,235$ because of unit pavers and stormwater management enhancements. While costs associated with this street were higher than a typical street design, the stormwater features help to mitigate area flooding. 


\section{Calculations:}

The Argyle Shared Street construction cost was $\$ 3,773,179$ for construction costs only, not including construction management or design fees (CDOT). Based on calculations provided by CDOT, the average City of Chicago block size of 333 feet was used to determine an average per block cost of $\$ 925,235$. In comparison, the CDOT provided costs for a nearby streetscape improvement project of similar size using standard materials and more typical improvements that included an asphalt street, no green infrastructure, and a limited amount of sidewalk pavers. The cost of this similarly sized, more typical project on Devon Avenue was $\$ 529,476$ per block. The Argyle Shared Street cost $\$ 395,759$ more per block than the more typical streetscape comparison on Devon Avenue. $(\$ 925,235$ - $\$ 529,476=\$ 395,759)$.

Limitations: Chicago Department of Transportation costs for a more typical street design are based on one nearby streetscape and may not reflect all of the City's different streetscape project costs. The expenses provided by the Center for Neighborhood Technology report are based on a survey conducted by the organization and are not all encompassing. In addition, they are not specific to the Argyle Shared Street Uptown neighborhood and the actual number and type of claims made by homeowners in the 60640 zip code is unknown. The Center for Neighborhood Technology report was based on flooding history from 2007 - 2011 and may not reflect the most current flooding costs or claims.

\section{Inconclusive Benefits}

\section{- Reduces the average air temperature by $1.45^{\circ} \mathrm{F}$ through the use of colored pavers that reflect more solar heat than conventional asphalt streets.}

Prior to construction, the street was composed of asphalt and concrete surfaces, both having low solar reflectance values and contributing to the urban heat island effect. The street reconstruction replaced these surfaces with $61,459 \mathrm{sf}$ of unit pavers with high solar reflectance values. Air temperature measurements were taken as the best available understanding of the effectiveness of the pavers.

Methods: Air temperature readings were taken in degrees Fahrenheit using a digital psychrometer at six distinct zones, two at full-sun, two at partial sun and two at shaded areas of the project site (Figure 1), as well as at a comparably sized and shaded conventional asphalt street sector on Wilson Avenue to serve as a control of a normal city street (Figure 2). An average of the six temperatures was taken at each site, the difference representing the air temperature difference between the two street conditions. 


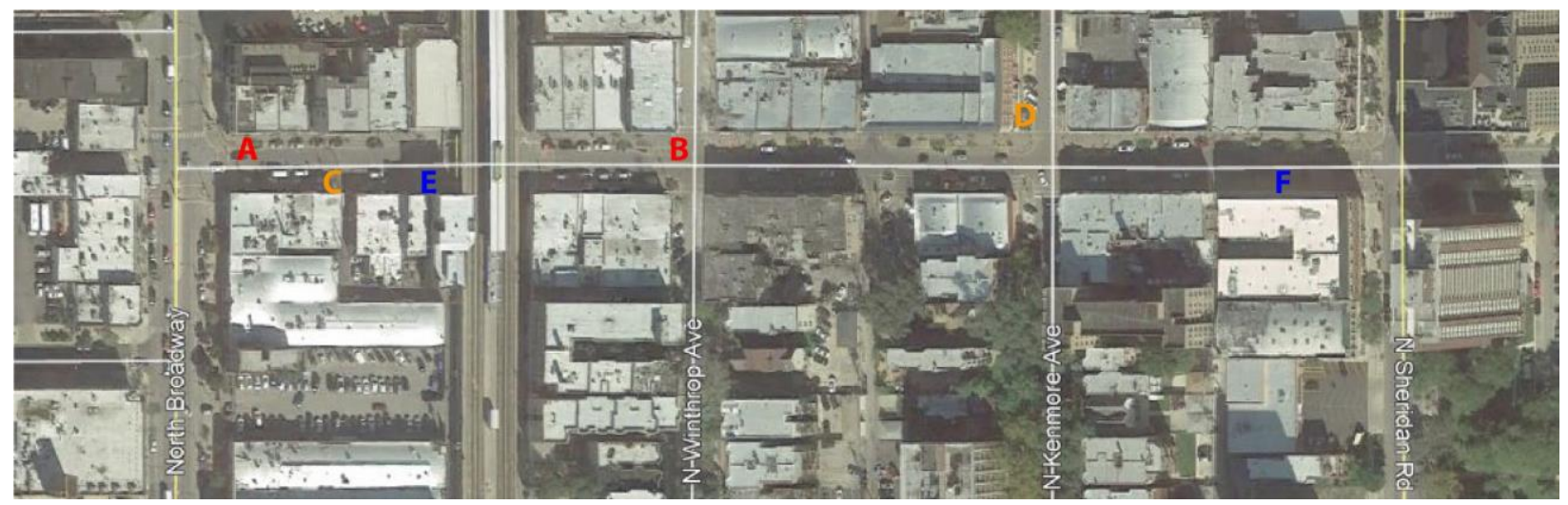

Figure 7: Argyle Shared Street Air Temperature Reading Locations

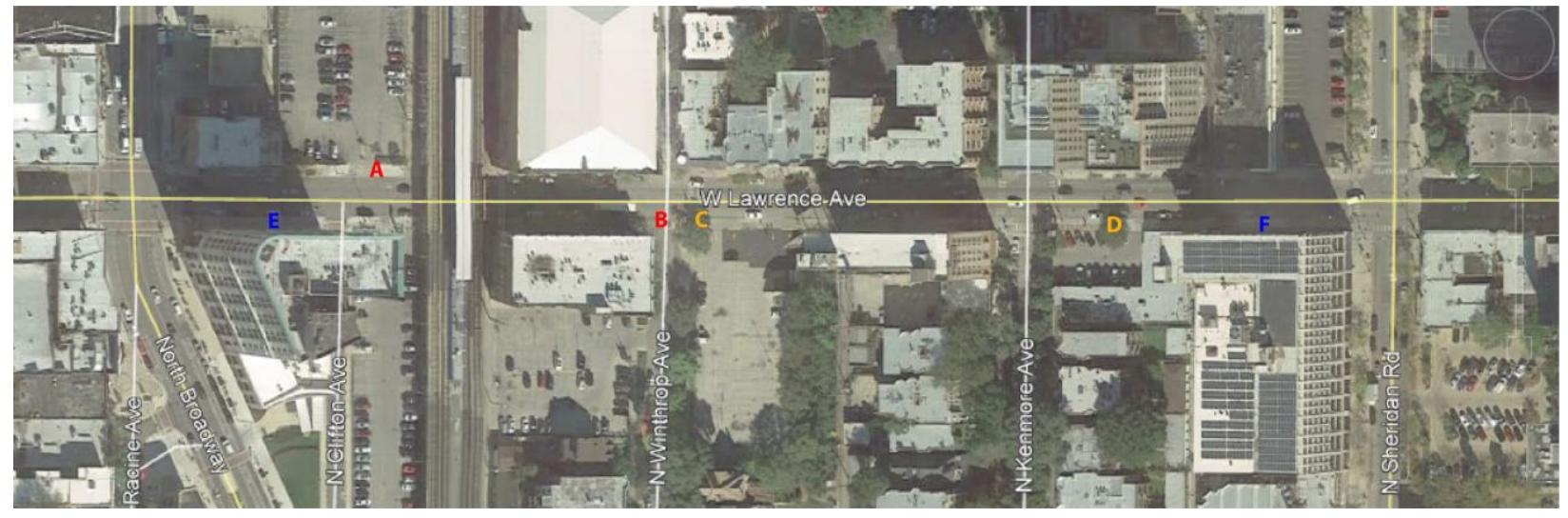

Figure 8: Lawrence Avenue (Control) Air Temperature Reading Locations

Calculations:

\begin{tabular}{|l|c|c|}
\hline & Argyle Shared Street $\left({ }^{\circ} \mathbf{F}\right)$ & Lawrence Avenue ( $\left.{ }^{\circ} \mathbf{F}\right)$ \\
\hline Zone A (full sun) & 86.30 & 88.50 \\
\hline Zone B (full sun) & 87.50 & 89.80 \\
\hline Zone C (partial shade) & 85.10 & 85.10 \\
\hline Zone D (partial shade) & 83.10 & 83.50 \\
\hline Zone E (shade) & 82.30 & 82.20 \\
\hline Zone F (shade) & 78.40 & 82.30 \\
\hline Average Temperature & $\mathbf{8 3 . 7 8}$ & $\mathbf{8 5 . 2 3}$ \\
\hline $\begin{array}{l}\text { Temperature } \\
\text { Difference }\end{array}$ & $\mathbf{1 . 4 5}$ & \\
\hline
\end{tabular}

Table 10: Air Temperature at Argyle Shared Street and Control Street. Source: LAF Research Team 
Sources:

LAF Research Team. Air Temperature at Argyle Shared Street vs. Control. June 26, 2019. Raw data. Uptown, Chicago.

Limitations: The digital psychrometer has a margin of error of $.9^{\circ} \mathrm{F}$. With an air temperature difference of $1.45^{\circ} \mathrm{F}$ recorded between the two sites, this measurement is not significant and thus is an inconclusive benefit.

A more accurate psychrometer with a lower margin of error, or another tool, would need to be used to get more conclusive data. The comparable quality of the asphalt street is dependent on building heights and tree cover. Since the project site dead ends on one side of the street, this adds a layer of difficulty in finding a comparable street in the area. Wind is an additional factor that may have affected the psychrometer readings, though it was attempted to take reading when wind flow was low.

\section{- Catalyzed the investment of around \$1.4 million in improvements to adjacent businesses since project construction began.}

Uptown United encouraged more participation in business improvement rebate programs during and after the street's reconstruction, citing the new streetscape as an incentive for Argyle Street businesses to invest. Between 2015 and 2018, 29\% of the $\$ 1.4$ million of investment was generated by these grant programs. Furthermore, many Argyle businesses made investments in property renovation outside of the rebate program.

Methods: Data was gathered from Uptown United of businesses adjacent to the Argyle Shared Street project that participated in either the facade improvement or Small Business Improvement Fund (SBIF) programs for the years 2015-2018 and/or made other investments towards their businesses. Of the $\$ 1,435,143$, approximately $\$ 414,632$, or $29 \%$, was provided through grant funds. Total business investments in improvements from 2015 and 2018 were totaled in Table 9.

Calculations:

\begin{tabular}{|l|r|r|}
\hline Business & Investment Amount & Aid Received \\
\hline Andy Lam & $\$ 121,000$ & $\$ 85,250$ \\
\hline Kim Long 2 Inc. & $\$ 16,820$ & $\$ 13,453$ \\
\hline Immm Tong & $\$ 69,966$ & $\$ 32,972$ \\
Hai Yen Restaurant & $\$ 140,404$ & $\$ 72,500$ \\
Sun Wha BBQ & $\$ 109,920$ & $\$ 60,457$ \\
Hieu Minh Troung & $\$ 142,400$ & $\$ 100,000$ \\
\hline Hong Ngu & $\$ 107,010$ & $\$ 50,000$ \\
\hline
\end{tabular}




\begin{tabular}{|c|c|c|}
\hline \multirow[t]{2}{*}{ Chiu Quon Bakery } & $\$ 12,620$ & \\
\hline & $\$ 4,812$ & \\
\hline Foremost Liquors & $\$ 900$ & \\
\hline \multirow[t]{4}{*}{ Hai Yen Restaurant } & $\$ 10,972$ & \\
\hline & $\$ 600$ & \\
\hline & $\$ 3,600$ & \\
\hline & $\$ 90,000$ & \\
\hline Hong Ngu & $\$ 6,297$ & \\
\hline \multirow[t]{3}{*}{ Immm Rice \& Beyond } & $\$ 8,100$ & \\
\hline & $\$ 3,000$ & \\
\hline & $\$ 5,700$ & \\
\hline Mini Tx Pharmacy & $\$ 18,489$ & \\
\hline Medical Center & $\$ 8,000$ & \\
\hline \multirow[t]{2}{*}{ Nik Pejovic } & $\$ 45,000$ & \\
\hline & $\$ 9,532$ & \\
\hline Hon Kee Restaurant & $\$ 500,000$ & \\
\hline TOTAL & $\$ 1,435,143$ & $\$ 414,632$ \\
\hline
\end{tabular}

Table 9: Investments made by Argyle Street businesses from 2015-2018.

Source: Uptown United

In an Argyle Shared Street Business Owner Survey distributed by paper and Google Form by the LAF Research Team in July $2019,7 / 10$, or $70 \%$, of businesses reported that the street redesign and reconstruction was not worth it for their business, or that it made no difference or they were unsure (Figure 4). This reflects an impression by business proprietors that the street's redesign was not a contributing factor to their decision to make investments in their businesses, also reflected by $6 / 9$, or $67 \%$ saying that the reconstruction did not affect their decision to participate or not participate in a financial improvement program (Figure 5). However, 7/10, or $70 \%$, or businesses reported that they find the street to be a more attractive place to have a business after the streets reconstruction (Figure 6). This paradox reflects the subjectivity of human opinion. The actual (not only perceived) benefits to businesses could not be measured within the time frame of this study. The full business owner survey is found in Appendix B.

The results of the Business Owner Survey somewhat undermine the concept of the Shared Street as a catalyst for improvements, since $66.7 \%$ of 10 respondents reported that the reconstruction did not influence their decision to participate in the financial improvement program. 
15. Do you feel the street redesign and construction was worth it for your business?

10 responses

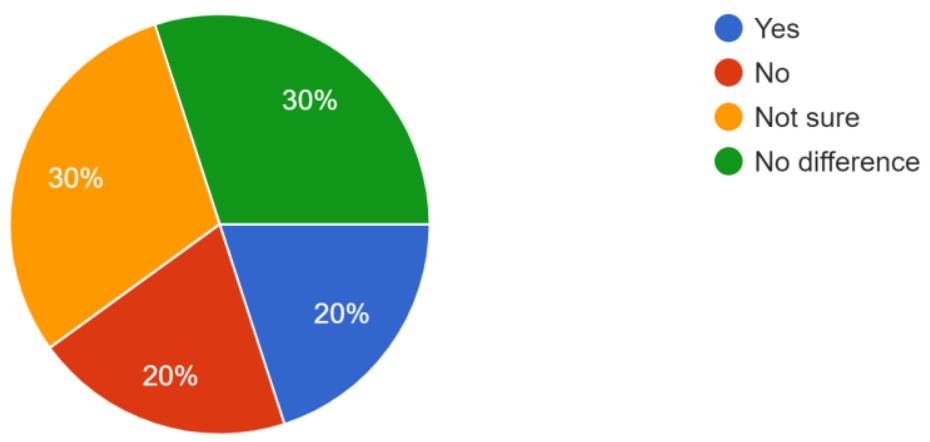

Figure 4: Business responses to impacts of construction as self-reported in July 2019.

Source: LAF Research Team

6. Did the reconstruction of the street influence your decision to participate in the financial improvement program?

9 responses

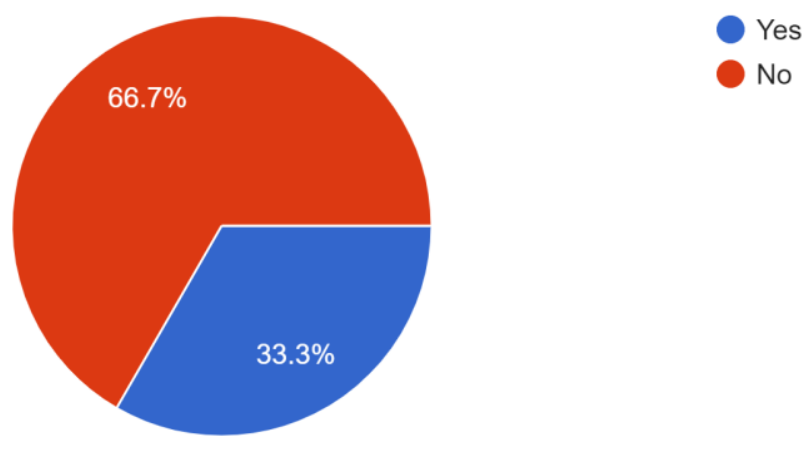

Figure 5: Street reconstruction's influence on participation in financial improvement program as selfreported by business in July 2019. Source: LAF Research Team 
9. Do you find this street to be a more attractive place to have a business after the street's reconstruction?

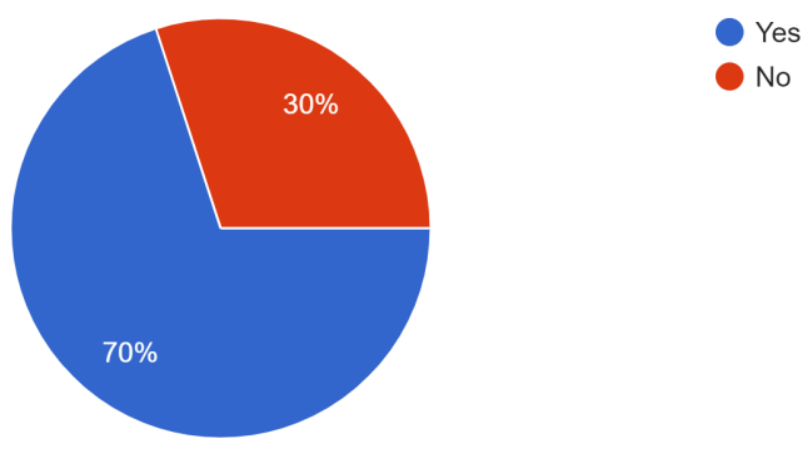

Figure 6: Business perception of street reconstruction's attractiveness for business as self-reported in July 2019. Source: LAF Research Team

Sources:

Callone, Matt. Argyle Shared Street Business Owner Survey. July 2019. Raw data. Uptown, Chicago.

Uptown United. Investments made by Argyle Street businesses from 2015-2018. Raw data. Argyle Shared Street, Chicago.

- Contributed to a $13 \%$ increase in property values of properties adjacent to Argyle Shared Street. New building projects nearby include 700 luxury apartments and the Timeline Theatre.

New business locations are planned as of 2019, such as Timeline Theatre and The Draper apartments planned for 700 apartment units.

Methods: The Cook County Property Tax Portal was utilized to determine the property value from 2015 to 2018 of 10 randomly selected properties on the Argyle Shared Street corridor from Sheridan Avenue to Broadway. For each property selected, the percent change from the previous year was calculated from 2016 to 2018, and the percent change from 2015 to 2018 was calculated. The average percent change was taken to get a $13 \%$ increase in property values from 2015 to 2018.

Uptown United provided the names of businesses opening soon on Argyle Street or nearby on Broadway. The LAF Research Team distributed surveys to Argyle Street businesses in person and emailed the survey via a Google Form link. 4/11 of the businesses that completed the survey opened the business during or after 2016. The full survey is found in Appendix B. 
Calculations:

\begin{tabular}{|c|c|c|c|c|c|}
\hline \multirow[b]{2}{*}{ Years } & \multicolumn{4}{|c|}{$\begin{array}{l}\text { Property Value (\$) and Percent Change from Previous } \\
\text { Year }\end{array}$} & \multirow{2}{*}{$\begin{array}{l}\text { Percent } \\
\text { Change from } \\
2015-2018\end{array}$} \\
\hline & 2015 & 2016 & 2017 & 2018 & \\
\hline \multicolumn{6}{|c|}{ Adjacent Properties - Argyle Avenue from Sheridan to Broadway } \\
\hline \multirow[t]{2}{*}{1129 W Argyle St } & \multirow[t]{2}{*}{$\$ 116,228$} & $\$ 116,228$ & $\$ 116,228$ & $\$ 137,584$ & $18 \%$ \\
\hline & & $0 \%$ & $0 \%$ & $18 \%$ & \\
\hline \multirow[t]{2}{*}{1134 W Argyle St } & \multirow[t]{2}{*}{$\$ 85,555$} & $\$ 85,555$ & $\$ 75,452$ & $\$ 117,097$ & $37 \%$ \\
\hline & & $0 \%$ & $-12 \%$ & $55 \%$ & \\
\hline \multirow[t]{2}{*}{1127 W Argyle St } & \multirow[t]{2}{*}{$\$ 46,654$} & $\$ 51,219$ & $\$ 66,229$ & $\$ 46,303$ & $1 \%$ \\
\hline & & $10 \%$ & $29 \%$ & $-30 \%$ & \\
\hline \multirow[t]{2}{*}{1100 W Argyle St } & \multirow[t]{2}{*}{$\$ 81,984$} & $\$ 81,984$ & $\$ 81,984$ & $\$ 71,624$ & $-12 \%$ \\
\hline & & $0 \%$ & $0 \%$ & $-13 \%$ & \\
\hline \multirow[t]{2}{*}{1059 W Argyle St } & \multirow[t]{2}{*}{$\$ 20,285$} & $\$ 20,285$ & $\$ 20,285$ & $\$ 28,815$ & $42 \%$ \\
\hline & & $0 \%$ & $0 \%$ & $42 \%$ & \\
\hline \multirow[t]{2}{*}{1057 W Argyle St } & \multirow[t]{2}{*}{$\$ 78,038$} & $\$ 26,232$ & $\$ 26,232$ & $\$ 60,000$ & $-23 \%$ \\
\hline & & $-66 \%$ & $0 \%$ & $128 \%$ & \\
\hline \multirow[t]{2}{*}{1054 W Argyle St } & \multirow[t]{2}{*}{$\$ 274,230$} & $\$ 274,230$ & $\$ 274,230$ & $\$ 354,560$ & $29 \%$ \\
\hline & & $0 \%$ & $0 \%$ & $29 \%$ & \\
\hline \multirow{2}{*}{$\begin{array}{l}5050 \mathrm{~N} \\
\text { Broadway }\end{array}$} & \multirow{2}{*}{$\begin{array}{l}\$ 1,336,899 \\
85 \%\end{array}$} & $\$ 1,336,900$ & $\$ 1,336,901$ & $\$ 830,211$ & $-38 \%$ \\
\hline & & $0 \%$ & $0 \%$ & $38 \%$ & \\
\hline \multirow{2}{*}{$\begin{array}{l}5014 \mathrm{~N} \\
\text { Broadway }\end{array}$} & \multirow[t]{2}{*}{$\$ 68,000$} & $\$ 68,000$ & $\$ 68,000$ & $\$ 115,726$ & $70 \%$ \\
\hline & & $0 \%$ & $0 \%$ & $70 \%$ & \\
\hline \multirow{2}{*}{$\begin{array}{l}5000 \mathrm{~N} \\
\text { Broadway }\end{array}$} & \multirow[t]{2}{*}{$\$ 232,681$} & $\$ 232,681$ & $\$ 232,681$ & $\$ 253,819$ & $9 \%$ \\
\hline & & $0 \%$ & $0 \%$ & $9 \%$ & \\
\hline Average & $\$ 111,517$ & $\$ 229,331$ & $\$ 229,822$ & $\$ 201,574$ & $13 \%$ \\
\hline
\end{tabular}

Table 11: Property Values and Percent Changes from 2015 to 2018 of Argyle Street properties between Sheridan Avenue and Broadway. Source: Cook County Tax Portal 


2. What year did you open your business at this location?
2017
1987
2017
2018
1990
1997
2004
1998
1988
2005
2018

Table 12: Years that Argyle businesses self-reported having opened, provided in July 2019. Source: LAF Research Team

Sources:

Callone, Matt. Argyle Shared Street Vendor Survey. July 2019. Raw data. Uptown, Chicago.

Cook County Property Tax Portal. Accessed July 30, 2019.

http://www.cookcountypropertyinfo.com/default.aspx.

Limitations: A consistent trend of property value growth for the businesses analyzed was not observed. Business growth trends seen of development along Broadway around Argyle Shared Street are comparable to growth trends on nearby Wilson Avenue. Many of the new Argyle business owners are children of business owners on Argyle Street having been located there for a very long time, or are similarly themed Asian themed businesses. As such, these common growth trends and cultural factors in developing on and around Argyle Street do not show a significant trend in development related to the street's reconstruction. 


\section{Appendix A:}

\section{7-11-2019 Argyle Event Visitor Survey}

Argyle Shared Street was constructed between N Broadway and Sheridan Road, this redevelopment opening in November 2016. This survey is being taken to measure the social, environmental and economic impacts of this redevelopment. Please respond as best as possible to the following questions.

1. Have you been to this street before?
a. Yes
b. No

2. If you have visited before, was it prior to the reconstruction and design of the current street layout, which was completed in 2016?
a. Yes
b. No

3. When visiting this street, generally how much time do you spend here?
a. 10 minutes or less
b. 11 minutes to 30 minutes
c. 31 minutes to 60 minutes
d. Over 1 hour

4. Do you spend more, less or the same amount of time on this street than previously? (Please circle one)
a. More time
b. Less time
c. Same amount of time

5. Do you find this street to have improved the quality of any of the following categories in comparison with a typical street design in Chicago? (Please select all that apply)
a. Aesthetic
b. Environmental
c. Cultural
d. Accessibility
e. No better quality

6. Are you aware of the environmentally sustainable features on the street? (Please circle one)
a. Yes
b. No

7. If you answered yes to question 7 above, please list one or more of the sustainable features you are aware of on this street. 
8. What attracts you to this street?
a. Restaurants
b. Retail
c. Gardens/plant features
d. Cultural aspects
e. Other

9. Outside of today's event, if you patronize any business on the street, what type?
a. Restaurant/Cafe
b. Retail
c. Grocery
d. Personal care (i.e. barbershop, nail salon)

10. How do you typically pass through or arrive at this street?
a. Bike
b. Walk
c. Public transportation - bus or train
d. Car

11. Do you find this street easier to navigate and cross than typical Chicago streets?
a. Yes
b. No

12. How do you typically cross this street?
a. I generally cross this street at the crosswalk more often than other typical Chicago streets.
b. generally cross this street at the crosswalk less often than other typical Chicago streets.
c. I generally cross this street at the crosswalk the same as I would at other typical Chicago streets.
d. I generally cross this street somewhere in the middle of the block more often than other typical Chicago streets.
e. I generally cross this street somewhere in the middle of the block less often than other typical Chicago streets.
f. I generally cross this street somewhere in the middle of the block the same as I would at other typical Chicago streets.

13. Do you live in the Uptown neighborhood?
a. Yes
b. No

14. Have you attended any events on this street before? 

a. Yes
b. No

15. If you've been to events, do you like coming to events on this street more or less compared to other streets?
a. More
b. Less
c. The same

16. Why do you like events on this street? (Please select all that apply.)
a. The layout of the street makes events easy to navigate.
b. I like to participate in the activities available at events on this street.
c. I enjoy the cultural aspect of events on this street.
d. All of the above
e. Other:

17. Do you think that this street offers something different than other similarly sized streets, like Lawrence, Berwyn, or Wilson? If so, what?

18. Does this street offer particular amenities/elements that other typical Chicago streets do not have?

19. If you live on Argyle Street, adjacent to the shared street, or on a cross street within a block of Argyle Shared Street, have you experienced flooding at your home?

a. Yes, before the street reconstruction

b. Yes, after the street reconstruction

c. Yes, before and after the street reconstruction

d. No

\section{Appendix B:}

Full Survey Results of Argyle Shared Street Business Owner Survey, collected in July 2019 For Publication: Argyle Shared Street Business Owner Survey 